\title{
Influence of Personality Introvert and Extrovert to Formation of Emotional Intelligence
}

\author{
Maulidiyah Junnatul Azizah Heru ${ }^{1}$, Handono F rahman ${ }^{2}$, Sri Minarti ${ }^{3}$, Sri Astutik \\ Andayani $^{4}$, Zainal Munir ${ }^{5}$, Kholisotin ${ }^{6}$ \\ Health Faculty, Nurul Jadid University, Paiton, Probolinggo, Indonesia ${ }^{1,2,4,5,6}$ \\ Tarbiya Faculty, Institut Agama Islam Sunan Giri, Bojonegoro, Indonesia ${ }^{3}$ \\ \{maulidiyah.junnatul.azizah-2018@fkp.unair.ac.id ${ }^{1}$, handono.hfc@gmail.com², sri.arti10@gmail.com³, \\ astutikandayani7@gmail.com ${ }^{4}$, zainalmunirnj@gmail.com ${ }^{5}$, nerslilis18@yahoo.co.id ${ }^{6}$ \}
}

\begin{abstract}
This study aims to prove the influence of introvert and extrovert personality on the formation of emotional intelligence (in class $\mathrm{x}$ in Darul Lughah Wal Madrasah Ali Karomah Sidomukti Kraksaan Probolinggo). The design used is cross sectional , use simple random sampling with a sample of 95 students from a total population of 130 students. In this study there were 29 introverted students, 66 extroverted students, 38 students with moderate emotional intelligence, 57 students had a high level of emotional intelligence. The Kolmogorov Smirnov test results obtained P-Value 0,000 and that value $0,000<0.05$ with a correlation value of 1 in the direction of a positive correlation $(+)$. Thus it can be concluded that Introverted and Extroverted Personality has an effect on the Formation of Class X Emotional Intelligence in Darul Lughah Wal Madrasah Ali Karomah Sidomukti Kraksaan Probolinggo.
\end{abstract}

Keywords: Introverted Personality, Extroverted Personality, Emotional Intelligence

\section{Introduction}

Every human being has a different and unique type of personality. This difference is a characteristic of each individual that will be seen in everyday life.

Eysenck suggested that there are two kinds of human personality types, namely introvert and extrovert. According to Eysenck, "Introverted people show a tendency to develop symptoms of fear and depression, which are characterized by tendency to obsession, irritability, apathy; their autonomic nerves are labile. While introverts are sociable, agile, active, assertive, looking for sensations, cheerful, dominant [1].

Alwisol said personality is "a part of the soul that builds human existence into a single entity, not divided into functions. Understanding personality means understanding me, myself, self, or understanding a whole person [2] From the differences in attitude between the two personalities it is clearly seen that there are differences in dealing with problems in life that are directly related to emotional intelligence .

Daniel Goleman shows that emotional intelligence is as important as intellectual intelligence, emotional intelligence which refers to the ability to recognize our own feelings 
and the feelings of others, the ability to motivate ourselves, and the ability to manage emotions well on ourselves, and in relationships with others [3].

Of course, every human being is influenced by these two factors, both outside the educational environment and in the educational environment. One of the goals of the learning process is the change in behavior related to the perfect blend of aspects of knowledge (cognitive) related to intelligence intelligence [4], aspects of attitude (affective) related to emotional intelligence, and psychomotor aspects.

According to Paul B. Horton personality is influenced by several factors, namely biological heritage, physical environment, culture, group experience, and a person's unique experience [5].

According to Freud as described by Sumadi Suryabrata that the phase of development of individual personality, when viewed from personality dynamics, is divided into 6 phases, namely: oral, anal, phallic, latent, puberty, and genital phases. After passing through the genital phase, finally entering the phase of maturity and dynamics, it has been calm and steady [6].

\section{Introvert and Extrovert Personality}

According to CG Jung, based on the attitude of the soul, humans can be classified as extroverted and introverted. Extroverted people are mainly influenced by the objective world. People who are introverted are more influenced by the subjective world [7].

Meanwhile, according to Sidharta, extroverted personality types tend to be attentive to their environment, to be sociable, to have moods that are easy to rise and fall, easy to express their emotions, impulsive in acting, dynamic, like change and adaptable to their environment. Individuals who have an introverted personality type are characterized by daydreaming, avoiding social contact, appearing calm, less expressive in their emotions, carefully considering before taking action, less dynamic, less like change, and not easy to adapt to their environment [8].

It can be understood according to Eysenck and Wilson that this tendency of extrovertintroverted personality types can be observed from seven factors that characterize a person's behavior namely Activity, Sociability, Risk Taking Impulsiveness Expressiveness Reflectiveness Responbility [9].

\section{Emotional intelligence}

Emotional Intelligence is not a new concept. In the early 1990s. Psychologists Peter Salovey and Jack Mayer proposed that individuals differ in their abilities to perceive, understand, and use their emotions. They labeled this ability emotional intelligence. The concept became more popular when Daniel Goleman wrote Emotional Intelligence [10].

Emotional Intelligence based on the results of research on neurology and psychology which shows that emotional intelligence is as important as intellectual intelligence. Based on the results of research by neurologists and psychologists, Goleman concluded that every human being has two potential thoughts, namely rational thoughts and emotional thoughts. Rational thinking is driven by intellectual abilities or popularly known as "Intelligence Quotient" (IQ), while emotional thoughts are driven by emotions, emotional intelligence refers to the ability to recognize our own feelings and other people's feelings, self-motivating 
abilities, and emotional management skills with good to yourself, and in relationships with other people [3].

The concept of emotional intelligence has to be done with a capacity that can be developed and guaranteed. The development of emotional intelligence allows us to have better control of our emotions and improve our social relations [11]. Broadly speaking, emotional intelligence contains the qualities and positive potentials of a person who is interpersonal and extrapersonal. These qualities are empathy, expressing and understanding feelings, controlling anger, independence, ability to adjust, being liked, ability to solve personal problems, perseverance, solidarity, friendliness, and respect for others [12].

According to Goleman, "the characteristics that indicate emotional intelligence are the ability to motivate oneself and survive when faced with frustration, controlling impulses, and not exaggerating pleasure, regulating moods, and keeping stress loads from paralyzing the ability to think, empathize and pray [12]. Furthermore, this ability can be categorized into five main regions namely knowing one 'emotions-self-awareness, managing emotions, motivating oneself, recognizing emotions in other (empathy), and handling relationships [3] Goleman said that emotional intelligence is also influenced by internal and external factors, including brain factors, family factors, school environmental factors [13], environmental factors and social support [12].

\section{Research Method}

Based on the problems studied, namely the Introvert and Extrovert Personality Effects on Emotional Intelligence Formation (in Class X in Senior High School at Darul Lughah Wal Karomah Sidomukti Kraksaan Probolinggo) "the form of this study is quantitative, with cross sectional research, the population in this study are all students class x in Darul Lughah Wal Karomah Islamic School which numbered 130 students. The sampling technique in this study was simple random sampling with a sample of 95 students. The instrument used in this study was the questionnaire. The questionnaire in this study has been tested for validity using the Pearson Product Moment formula . Furthermore, the data is analyzed using the Kolmogorov Smirnov test and Lambda test to measure the strength of the relationship or influence between variables with one another.

\section{Result}

Table 1. Frequency introvert and personality extrovert in class X students at Aliyah Darul Madrasah Lughah Wal Karomah Sidomukti Kraksaan Probolinggo

\begin{tabular}{ccc}
\hline Personality & $\sum$ & $\%$ \\
\hline Introvert & 29 & 30 \\
Extrovert & 66 & 70 \\
total & 95 & 100 \\
\hline
\end{tabular}

From table 1 obtained that personality students class $\mathrm{x}$ on senior High School Darul Lughah Wal Karomah there are 29 students (30\%) with introverted personality and 66 
students $(70 \%)$ had personality extrovert, so of 95 students who became respondent more many have personality extrovert from on introverted personality.

Table 2. Frequency of intelligence level emotional in class x Students at Aliyah Darul Madrasah Lughah Wal Karomah Sidomukti Kraksaan Probolinggo

\begin{tabular}{ccc}
\hline $\begin{array}{c}\text { Intelligence Level } \\
\text { Emotional }\end{array}$ & $\sum$ & $\%$ \\
\hline Low & $\mathbf{0}$ & $\mathbf{0}$ \\
Is being & $\mathbf{3 8}$ & $\mathbf{4 0}$ \\
High & $\mathbf{5 7}$ & $\mathbf{6 0}$ \\
total & $\mathbf{9 5}$ & $\mathbf{1 0 0}$ \\
\hline
\end{tabular}

From table 2 in on obtained level intelligence emotional students class $\mathrm{x}$ on senior High School Darul Lughah Wal Karomah 38 students (40\%) have moderate levels of emotional intelligence, 57 students $(60 \%)$ have a high level of emotional intelligence and no class $\mathrm{X}$ students have a low level of emotional intelligence.

Table 3. Frequency of level of emotional intelligence in class X students who have introvert and extrovert personality in Darul Lughah Wal Madrasah Aliyah Karomah Sidomukti Kraksaan Probolinggo

\begin{tabular}{ccccc}
\hline $\begin{array}{c}\text { Intelligence } \\
\text { Level } \\
\text { Emotional }\end{array}$ & $\begin{array}{c}\text { Introverted } \\
\text { Personality }\end{array}$ & $\begin{array}{c}\text { Percentage } \\
\mathbf{( \% )}\end{array}$ & $\begin{array}{c}\text { Personality } \\
\text { Extrovert }\end{array}$ & $\begin{array}{c}\text { Percentage } \\
(\mathbf{\%})\end{array}$ \\
\hline Low & 0 & 0 & 0 & 0 \\
Is being & 29 & 100 & 9 & 13.6 \\
High & 0 & 0 & 57 & 86.4 \\
total & $\mathbf{2 9}$ & $\mathbf{1 0 0}$ & $\mathbf{6 6}$ & $\mathbf{1 0 0}$ \\
\hline
\end{tabular}

Based on table 3 above can be seen the level of intelligence emotional students with introverted personality with level intelligence emotional is being are 29 students $(100 \%)$, and not there is students with introverted personality have level intelligence high emotional and low.

Whereas in class X students in Darul Lughah Wal Madrasah Aliyah, Karomah Sidomukti Kraksaan Probolinggo, who have extroverted personalities, there are 57 students $(86.4 \%)$ who have a high level of emotional intelligence and 9 students $(13.6 \%)$ at moderate emotional levels and no students with extroverted personality have a low level of emotional intelligence. So not there is respondents who have level intelligence low emotional well respondents who have introverted personality or who have personality extrovert .

Table 4. Effects of Introverted and Extroverted Personality on the Formation of Emotional Intelligence in Class X Students at Darul Lughah Madrasah Wal Karomah Sidomukti Kraksaan Probolinggo

\begin{tabular}{|c|c|c|c|}
\hline Variable & Intelligence Level Emotional & & total \\
\hline Personality & Is being & High & $\sum \%$ \\
\hline
\end{tabular}




\begin{tabular}{llllllllll} 
& & $\sum$ & $\%$ & & $\%$ & $\%$ & $\%$ & & \\
& & & & & & & & & \\
\hline Introvert & 0 & 0 & 29 & 100 & 0 & 0 & 29 & 100 \\
Extrovert & 0 & 0 & 9 & 13.6 & 57 & 86.4 & 66 & 100 \\
$P$-Value & & & & & 0,000 & & & \\
\hline
\end{tabular}

Based on table 4 , after being tested with Kolmogorov Smirnov obtained Asymp. Sig. ( 2Tailed ) 0,000 ( P-Value 0,000) and that value $(0,000<0.05)$.

Table 5. Overview of the Lambda test

\begin{tabular}{lcccccc}
\hline Personality & \multicolumn{2}{l}{ Level Intelligence Emotional } & & Total & $\mathrm{R}$ & $\mathrm{P}$ \\
\cline { 2 - 4 } & Low & Is being & High & & & \\
\hline & 0 & 29 & 0 & 29 & & \\
Introvert & 0 & 9 & 57 & 66 & & 0.157 \\
Extrovert & 0 & 38 & 57 & 95 & & \\
total & & & & & & \\
\end{tabular}

Based on table 5 above using the Lambda test obtained P-Value 1 and this value is greater than the aprrox value sig . $0.157(1>0.157)$ and it can be concluded that the strength of the relationship between the independent variable and the dependent variable is interpreted very strongly so that the correlation direction is positive $(+)$.

\section{Conclusion}

Based on the results of data analysis that has been done, it can be concluded as follows: From this study it can be concluded that there are 29 students $(30 \%)$ with introverted personality, 66 students $(70 \%)$ extroverted personality, 38 students $(40 \%)$ with emotional intelligence moderate, 57 students $(60 \%)$ have a high level of emotional intelligence, judging by the level of intelligence emotional students with introverted personality with level intelligence emotional is being are 29 students $(100 \%)$, and not there is students with introverted personality have level intelligence high emotional and low, while those who have extroverted personality there are 57 students (86.4\%) have a high level of emotional intelligence and 9 students $(13.6 \%)$ are at the level of moderate emotional intelligence and no students with extroverted personality have a low level of emotional intelligence . and there is the influence of introverted and extroverted personality on the formation of emotional intelligence of class X students at Darul Lughah Wal Karomah Islamic School.

\section{References}

[1] S. in Suryabrata, Personality Psychology. Jakarta: PT RajaGrafindo Persada, 2005.

[2] Alwisol, Personality Psychology. Malang: UMM Press, 2014. 
[3] Desmita, Development Psychology. Bandung: PT Remaja Rosdakarya, 2012.

[4] C. Muali, S. Islam, and M. M. E. I. Bali, "Free Online Learning Based On Rich Internet Applications; The Experimentation Of Critical Thinking About Student Learning Style," J. Phys. Conf. Ser., vol. 1114, pp. 1-6, 2018.

[5] J. S. Kun Maryati, Sociology for high school and MA class X. Jakarta: Gelora Aksara Pratama, 2007.

[6] Sunaryo, Psychology for Nursing. Jakarta: EGC, 2004.

[7] A. J. N. Syamsu Yusuf, Personality Theory, vol. 1, no. 2. Bandung: PT Remaja Rosdakarya, 2011.

[8] D. Pamuncak, "Effect of Personality Type on Facebook users' Self Disclosure," UIN Syarif Hidayatullah, Jakarta, 2011.

[9] M. Yolles, Organizations as Complex Systems: An Introduction to Cybernetic Knowledge. USA: IAP, 2006.

[10] M. Sallie-Dosunmu, "Using Emotional Intelligence in The Workplace," Career Dev., vol. 33, 2016.

[11] J. M. de La Serna, Emotional Intelligence in School. Tektime, Chapter 4, 2018.

[12] Muallifah, Psycho Islamic Smart Parenting. Yogyakarta: Diva Press, 2009.

[13] H. Baharun, "Pengembangan Media Pembelajaran PAI Berbasis Lingkungan Melalui Model ASSURE,” Cendekia J. Educ. Soc., vol. 14, no. 2, pp. 231-246, 2016. 